- FINANSE I PRAWO FINANSOWE.

- Journal of Finance and Financial Law •

Czerwiec/June 2018 • vol. 2(18): 79-90

https://doi.org/10.18778/2391-6478.2.18.07

\title{
DZIAŁALNOŚĆ KOMPENSACYJNA UBEZPIECZENIOWEGO FUNDUSZU GWARANCYJNEGO W POLSCE W LATACH 2012-2016
}

\author{
Joanna Urbanek ${ }^{1}$ \\ Wydział Ekonomiczno Socjologiczny \\ Uniwersytet Łódzki
}

\section{Streszczenie}

Ubezpieczeniowy Fundusz Gwarancyjny pełni unikatową rolę na polskim rynku ubezpieczeniowym. Jako jedyna instytucja w sposób kompleksowy chroni ubezpieczonych i poszkodowanych. W artykule omówiono misje i sposób działania UFG. Przedstawiono analizę realizacji funkcji kompensacyjnej w latach 2012-2016 i dokonano jej interpretacji. Wykazano, że zapotrzebowanie na usługi świadczone przez UFG rośnie.

Słowa kluczowe: Ubezpieczeniowy Fundusz Gwarancyjny (UFG), Odpowiedzialność Cywilna (OC), zakłady ubezpieczeń, ubezpieczenie obowiązkowe, funkcja kompensacyjna.

JEL Class: G22, G28.

1 Opiekun naukowy dr Anna Piechota, Instytut Finansów, Wydział Ekonomiczno-Socjologiczny, Uniwersytet Łódzki. 


\section{WPROWADZENIE}

W 1991 roku, w wyniku niewystarczającej szczelności systemu ubezpieczeniowego i braku możliwości zapewnienia ochrony ubezpieczonym, do życia powołano Ubezpieczeniowy Fundusz Gwarancyjny. Jego głównymi zadaniami miało być wypłacanie świadczeń i odszkodowań osobom poszkodowanym i uprawnionym, zapewnienie wypłat poszkodowanym w przypadku niewypłacalności ubezpieczyciela, sprawowanie kontroli nad obowiązkiem posiadania ubezpieczenia OC przez posiadaczy pojazdów mechanicznych oraz rolników, a także gromadzenie i udostępnianie wybranych danych dotyczących rynku ubezpieczeń. Głównym celem pracy jest przedstawienie efektów realizacji funkcji kompensacyjnej przez UFG w Polsce w latach 2012-2016. W badaniach wykorzystano dane ilościowe zawarte w Raportach Rocznych UFG w analizowanym okresie.

\section{ISTOTA UFG}

Ubezpieczeniowy Fundusz Gwarancyjny (UFG) jest instytucją odpowiedzialną za zabezpieczenie interesów osób ubezpieczonych i wypłatę świadczeń, w sytuacji, gdy podmiot ubezpieczeniowy lub sprawca zdarzenia nie są w stanie wywiązać się ze swych zobowiązań [Iwanicz-Drozdowska 2013: 80]. Ubezpieczeniowy Fundusz Gwarancyjny funkcjonuje na polskim rynku od 1991 roku. W latach 1990-1995 istniały w Polsce dwie instytucje gwarancyjne - Ubezpieczeniowy Fundusz Gwarancyjny, działający w charakterze samochodowego funduszu gwarancyjnego oraz Fundusz Ochrony Ubezpieczonych (FOU), zajmujący się wypłacaniem należnych świadczeń i odszkodowań w przypadku upadłości zakładów ubezpieczeń majątkowych i zakładów ubezpieczeń na życie. W drodze nowelizacji ustawy z dnia 28 lipca 1990 roku o działalności ubezpieczeniowej, prawa i obowiązki FOU zostały przejęte przez UFG, co jednocześnie spowodowało, że UFG stał się jedyną instytucją gwarancyjną na polskim rynku ubezpieczeniowym [Nowak i in. 2009: 175]. Głównym powodem utworzenia Ubezpieczeniowego Funduszu Gwarancyjnego było przekonanie, że dotychczasowy system ubezpieczeniowy nie jest szczelny i nie zapewnia poszkodowanym właściwej ochrony - istniejący wówczas system ubezpieczeniowy stanowił zabezpieczenie tylko wtedy, gdy spełnione zostały następujące przesłanki: sprawca szkody był znany, sprawca szkody/posiadacz pojazdu mechanicznego/rolnik był odpowiedzialny cywilnie za wyrządzoną szkodę oraz posiadali oni umowę ubezpieczenia OC zawartą z wybranym zakładem ubezpieczeń. W związku z powyższym, kluczowym celem utworzenia UFG było umożliwienie naprawienia szkody wyrządzonej 
ruchem mechanicznego środka komunikacji, w przypadku gdy osoba odpowiedzialna za powstanie szkody nie dopełniła obowiązku zawarcia umowy ubezpieczenia OC lub nie została zidentyfikowana [Kwiecień 2011: 169].

Do członków UFG należą krajowe i zagraniczne zakłady ubezpieczeń, które prowadzą na terenie Rzeczpospolitej Polskiej działalność ubezpieczeniową z zakresu obowiązkowego ubezpieczenia OC dla rolników i posiadaczy pojazdów mechanicznych [Szaraniec 2013: 141]. Misją UFG jest zapewnienie szczelności systemu obowiązkowych ubezpieczeń od odpowiedzialności cywilnej poprzez ograniczenie liczby nieubezpieczonych posiadaczy pojazdów oraz osób prowadzących gospodarstwa rolne [Ubezpieczeniowy Fundusz Gwarancyjny, Misja Fundusz, dostęp: 18.02.2018]. Środki przekazywane na funkcjonowanie UFG pochodzą przede wszystkim z obowiązkowych składek wnoszonych przez zakłady ubezpieczeń, które są w zamian objęte gwarancją UFG. Innymi źródłami finansowania UFG są dochody wynikające $\mathrm{z}$ lokowania wolnych środków w instrumenty finansowe oraz uiszczane kary przez osoby, które nie wywiązały się z obowiązku zawarcia obligatoryjnego ubezpieczenia [Sangowski 1998: 136-137].

\section{FUNKCJE UFG}

Ubezpieczeniowy Fundusz Gwarancyjny w ramach swojej działalności pełni cztery funkcje: kompensacyjną, gwarancyjną, kontrolną oraz informacyjną.

Funkcja kompensacyjna polega na wypłacaniu świadczeń i odszkodowań osobom poszkodowanym oraz uprawnionym [Monkiewicz 2007: 46-47]. UFG w ramach swojej działalności podstawowej, zajmuje się zaspokajaniem roszczeń z tytułu obowiązkowych ubezpieczeń odpowiedzialności cywilnej posiadaczy pojazdów mechanicznych za szkody powstałe w wyniku ruchu tych pojazdów oraz odpowiedzialności cywilnej rolników z tytułu posiadanego gospodarstwa rolnego za szkody powstałe na terenie Rzeczpospolitej Polskiej [Ustawa z 22 maja 2003 r. o ubezpieczeniach obowiązkowych, Ubezpieczeniowym Funduszu Gwarancyjnym i Polskim Biurze Ubezpieczycieli Komunikacyjnych, art. 98 ust. 1 i 1 a]:

- na osobie - w przypadku, gdy została wyrządzona szkoda w okolicznościach uzasadniających odpowiedzialność cywilną, a nie ustalono tożsamości posiadacza pojazdu mechanicznego lub kierującego pojazdem mechanicznym. UFG wypłaca zadośćuczynienie, pokrywa koszty leczenia oraz wypłaca renty w przypadku trwałego uszczerbku na zdrowiu;

- w mieniu - w sytuacji szkody, podczas której jednocześnie u któregoś z uczestników wypadku nastąpiła śmierć, naruszenie czynności narządu ciała 
bądź rozstrój zdrowia trwający więcej niż 14 dni, a szkoda została wyrządzona w okolicznościach uzasadniających odpowiedzialność cywilną, lecz nie ustalono tożsamości posiadacza pojazdu mechanicznego lub kierującego pojazdem mechanicznym. W sytuacji szkody w pojeździe mechanicznym, świadczenie UFG ulega zmniejszeniu o kwotę będącą równowartością 300 euro, biorąc pod uwagę przy jej określeniu średni kurs ogłaszany przez Narodowy Bank Polski, obowiązujący w dniu ustalenia odszkodowania;

- w mieniu i na osobie, w sytuacji gdy:

- właściciel zidentyfikowanego pojazdu mechanicznego (lub kierujący pojazdem), którego ruchem wyrządzono szkodę, nie był w posiadaniu ubezpieczenia OC obowiązkowego dla posiadaczy pojazdów mechanicznych, posiadacz zidentyfikowanego pojazdu mechanicznego, którego ruchem wyrządzono szkodę, zarejestrowanego za granicami kraju na terytorium państwa, którego biuro jest sygnatariuszem Jednolitego Porozumienia między Biurami Narodowymi - Regulaminu Wewnętrznego, nie posiadał obowiązkowego ubezpieczenia OC posiadaczy pojazdów mechanicznych, a ponadto pojazd pozbawiony był znaków rejestracyjnych lub te znaki nie były w momencie zdarzenia przydzielone temu pojazdowi przez odpowiednie władze;

- rolnik, osoba pracująca w jego gospodarstwie rolnym lub osoba pozostająca z nim na wspólnym gospodarstwie domowym, wyrządzili szkodę, której następstwem była śmierć, uszkodzenie ciała, rozstrój zdrowia lub utrata, uszkodzenie bądź zniszczenie mienia, a rolnik nie posiadał obowiązkowego ubezpieczenia OC dla rolników.

W przypadku szkód wyrządzonych osobom pochodzącym z zagranicy, z państw, których biura nie są sygnatariuszami Jednolitego Porozumienia pomiędzy Biurami Międzynarodowymi - Regulaminu Wewnętrznego, UFG realizuje wypłatę odszkodowana na zasadach wzajemności [Pałczyńska-Mortka i Żmigodzki 2012: 166].

UFG nie realizuje wypłaty odszkodowania poszkodowanym, jeżeli zachodzi możliwość zaspokojenia przez nich roszczeń na podstawie umowy dobrowolnego ubezpieczenia (np. AC) - w takich przypadkach UFG wyrównuje szkody w części niezaspokojonej z ubezpieczenia dobrowolnego [Monkiewicz i Orlicki, 2015: 157].

Do UFG wpływają roszczenia osób ubezpieczonych lub uprawnionych do zgłoszenia szkody [Kwiecień 2011: 172]:

- bezpośrednio od osoby poszkodowanej lub uprawnionej do zgłoszenia szkody,

- za pośrednictwem zakładów wykonujących działalność w zakresie obowiązkowych ubezpieczeń, 
- za pośrednictwem Organu Odszkodowawczego, Polskiego Biura Ubezpieczycieli Komunikacyjnych lub korespondenta zagranicznego towarzystwa ubezpieczeniowego,

- od syndyka upadłości, w sytuacji ogłoszenia upadłości przez wybrany zakład ubezpieczeń, prowadzący działalność ubezpieczeniową z zakresu obowiązkowych ubezpieczeń.

Zgodnie z V dyrektywą komunikacyjną (2005/14/EC, zastąpioną przez tekst ujednolicony 2009/103/EC), wysokość gwarancji, w przypadku szkód wynosi [Ronka-Chmielowiec 2016: 365-366]:

- w mieniu - minimum 1 mln euro na jedno zdarzenie, bez względu na liczbę poszkodowanych osób,

- na osobie - minimum 5 mln euro na jedno zdarzenie, bez względu na liczbę poszkodowanych osób.

Funkcja gwarancyjna UFG jest realizowana w przypadku gdy zachodzi okoliczność niewypłacalności ubezpieczyciela, która ma miejsce w sytuacji ogłoszenia upadłości lub oddalenia wniosku ogłaszającego upadłość ubezpieczyciela, umorzenia postępowania upadłościowego, w sytuacji gdy majątek dłużnika nie wystarcza nawet na pokrycie kosztów postępowania upadłościowego czy w przypadku zarządzenia likwidacji przymusowej ubezpieczyciela. W takich sytuacjach, Fundusz w ramach tzw. „działalności z tytułu upadłości” zaspokają [Kwiecień 2011: 171]:

- w $100 \%$ (jednak nie wyżej niż do wysokości sumy gwarancyjnej) roszczenia osób uprawnionych:

- z umów obowiązkowych ubezpieczeń od odpowiedzialności cywilnej posiadaczy pojazdów mechanicznych,

- z umów obowiązkowych ubezpieczeń od odpowiedzialności cywilnej rolników oraz ubezpieczeń budynków składających się na gospodarstwo rolne od ognia i innych zdarzeń losowych;

- w 50\% roszczenia osób uprawnionych, z umów pozostałych ubezpieczeń obowiązkowych, a także umów ubezpieczenia na życie, do kwoty nie większej niż równowartość w złotówkach 30000 euro, według średniego kursu ogłaszanego przez Narodowy Bank Polski, obowiązującego w dniu ogłoszenia upadłości lub innej przyczyny będącej powodem niewypłacalności ubezpieczyciela.

Ubezpieczeniowy Fundusz Gwarancyjny jest także podmiotem uprawnionym do pełnienia kontroli nad spełnianiem obowiązku posiadania ubezpieczenia OC przez posiadaczy pojazdów mechanicznych oraz rolników. Nakłada i egzekwuje kary pieniężne za nieposiadanie obowiązkowego ubezpieczenia OC przez posiadaczy pojazdów mechanicznych, korzystając z informacji przekazywanych przez policję i inne służby oraz pozyskiwanych z Systemu Wykrywania Nieubezpieczonych Pojazdów (w 2014 roku prawie 50\% przypadków braku ubez- 
pieczenia OC posiadaczy pojazdów mechanicznych wykryto dzięki wirtualnym kontrolom prowadzonym przez UFG) [Turkowska-Tyrluk 2005: 22].

Ostatnia pełniona przez UFG funkcja, tj. funkcja informacyjna, polega na prowadzeniu Ośrodka Informacji. UFG gromadzi dane dotyczące rynku ubezpieczeń, a następnie udostępnia uprawnionym do tego podmiotom. Gromadzone dane i informacje dotyczą [Raport Roczny UFG 2016: 16, dostęp: 25.03.2018]:

- liczby zawartych polis ubezpieczenia komunikacyjnego (OC i AC),

- zdarzeń drogowych, które skutkują odpowiedzialności zakładów ubezpieczeń,

- liczby i wartości odszkodowań wypłacanych z zawartych polis ubezpieczeniowych.

\section{ANALIZA REALIZACJI FUNKCII KOMPENSACYJNEJ UFG W OPARCIU O RAPORTY ROCZNE UFG ZA LATA 2012-2016}

W niniejszym rozdziale przedstawiono efekty realizacji funkcji kompensacyjnej przez UFG w Polsce. Prezentacji dokonano przy wykorzystaniu danych z Raportów Rocznych UFG za lata 2012-2016.

\subsection{Liczba zgłoszonych szkód}

W latach 2012-2016 zostało zgłoszone łącznie 32032 szkód, z czego:

- 6243 w 2012 r.,

- 6099 w 2013 r.,

- 6203 w 2014 r.,

- $6950 \mathrm{w} 2015 \mathrm{r}$.,

- 6537 w 2016 r. [Raport Roczny UFG 2016: 9, dostęp: 25.03.2018].

Liczba zgłoszonych szkód wynosiła średnio 6406 na rok. W podziale na szkody z ubezpieczenia OC komunikacyjnego i rolników, zdecydowana większość przypada na szkody z tytułu OC posiadaczy pojazdów mechanicznych. Wynosiły one od 98,49\% do 99,1\% liczby wszystkich zgłoszonych szkód na przestrzeni lat 2012-2016, i mają wyraźnie tendencję rosnącą. Procent zgłoszonych szkód związanych z OC rolników wynosi od 1,51\% do 0,9\% wszystkich zgłoszonych szkód i sukcesywnie co roku maleje. Dane przedstawia wykres 1 . 


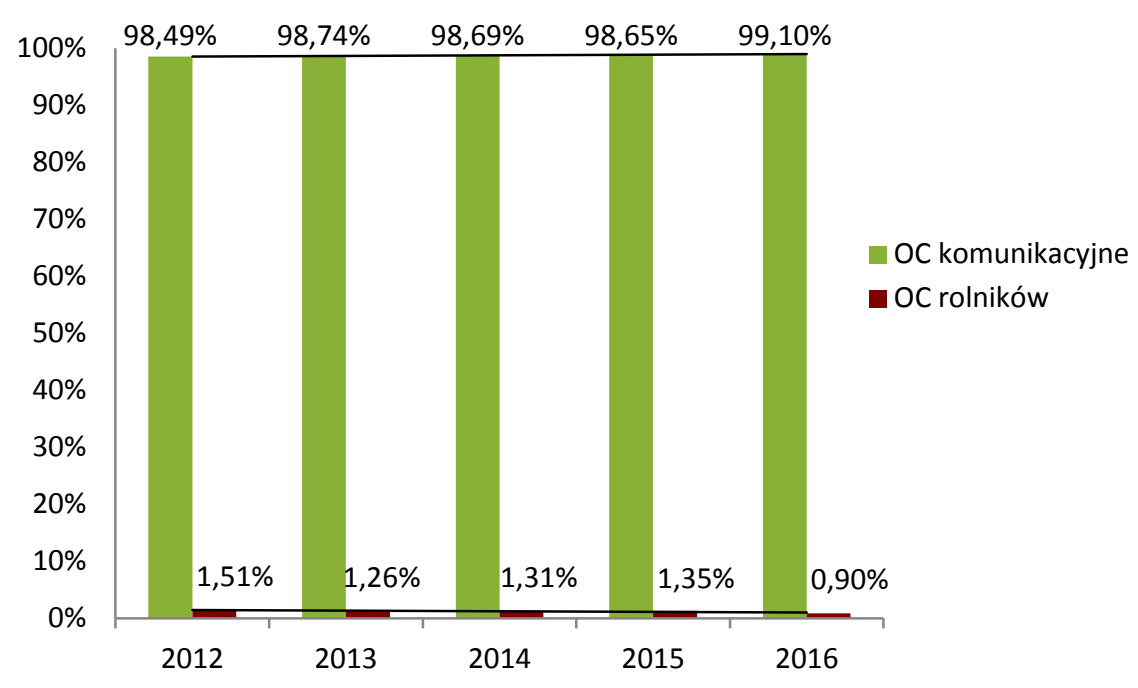

Wykres 1. Liczba zgłoszonych szkód w latach 2012-2016

Źródło: opracowanie własne na podstawie: Raporty roczne UFG 2016 [dostęp: 20.03.2018]; Raporty roczne UFG 2015 [dostęp: 20.03.2018]; Raporty roczne UFG 2014 [dostęp: 20.03.2018]; Raporty roczne UFG 2013 [dostęp: 20.03.2018]; Raporty roczne UFG 2012 [dostęp: 20.03.2018].

\subsection{Liczba wypłaconych zgłoszonych szkód}

W latach 2012-2016 UFG wypłacił łącznie rekompensatę w przypadku 27980 zgłoszonych szkód, co stanowiło 87,4\% wszystkich zgłoszeń. Liczba wypłaconych roszczeń na przestrzeni lat prezentowała się następująco:

- 4874 w 2012 r.,

- 5278 w 2013 r.,

- 7018 w 2014 r.,

- 5521 w 2015 r.,

- 5289 w 2016 r. [Raport Roczny UFG 2016: 9, dostęp: 24.03.2018].

$\mathrm{Na}$ przestrzeni analizowanych lat, najczęstszą przyczyną wypłacanych przez UFG świadczeń byli nieubezpieczeni sprawcy. Średnio stanowili oni przyczynę $75,9 \%$ liczby wypłaconych szkód. Drugą przyczyną byli nieznani sprawcy średnio $24,1 \%$ wszystkich świadczeń, trzecią zaś - rolnicy, którzy stanowi powód niespełna 1\% liczby wypłacanych roszczeń. Na wykresie 2 , zaprezentowano udział procentowy wypłaconych szkód ze względu na kategorię sprawcy szkody. 


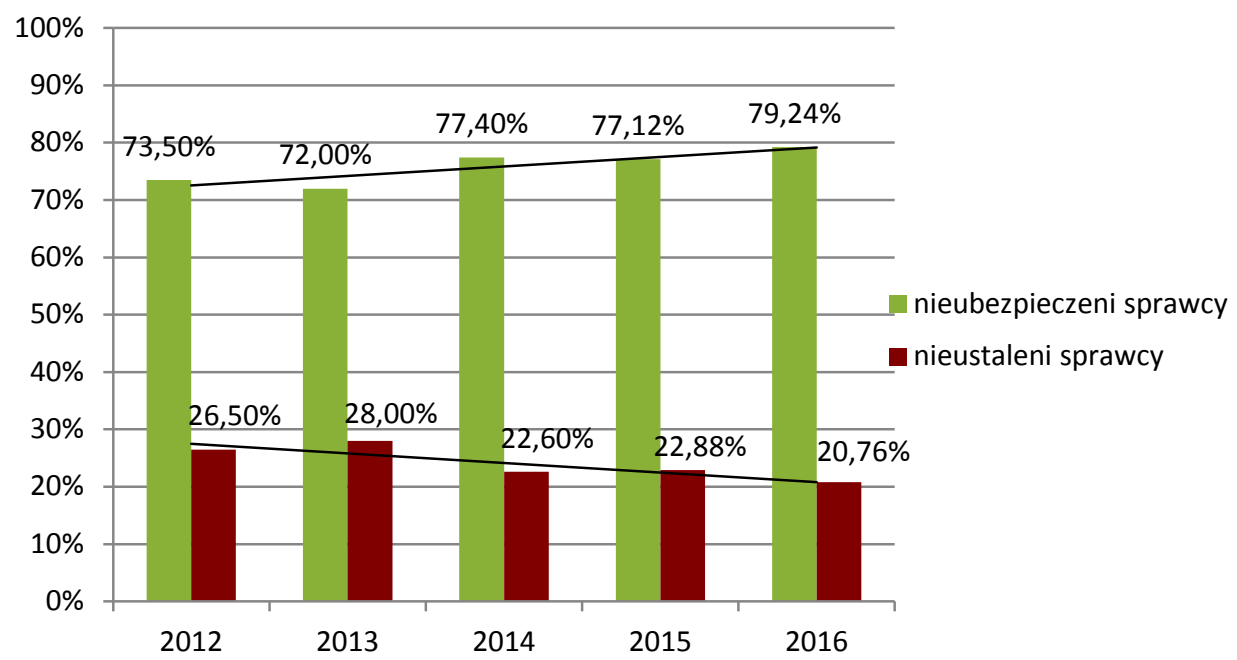

Wykres 2. Liczba wypłacanych szkód według sprawcy szkody w latach 2012-2016.

Źródło: opracowanie własne na podstawie: Raporty roczne UFG 2016 [dostęp: 20.03.2018]; Raporty roczne UFG 2015 [dostęp: 20.03.2018]; Raporty roczne UFG 2014 [dostęp: 20.03.2018]; Raporty roczne UFG 2013 [dostęp: 20.03.2018]; Raporty roczne UFG 2012, [dostęp: 20.03.2018].

\subsection{Liczba wypłaconych odszkodowań}

Liczba zgłoszonych szkód w stosunku do liczby wypłaconych odszkodowań w latach 2012-2016 wynosiła następująco:

- $78 \%$ w 2012 r.,

- $86,5 \%$ w 2013 r.,

- $113,1 \%$ w 2014 r.,

- $79,4 \%$ w 2015 r.,

- $80,9 \%$ w 2016 r.

Średnio realizowanych było $87,58 \%$ zgłoszeń o odszkodowania na rok. Najwięcej odszkodowań zostało wypłaconych w 2014 roku, pod względem ilościowym, jak i w stosunku do zgłoszonych roszczeń. Najmniejsza ilość wypłaconych odszkodowań przypadła na 2012 rok, a najmniejsza ilość odszkodowań procentowo w stosunku do liczby zgłoszeń na 2015 rok (wykres 3). 


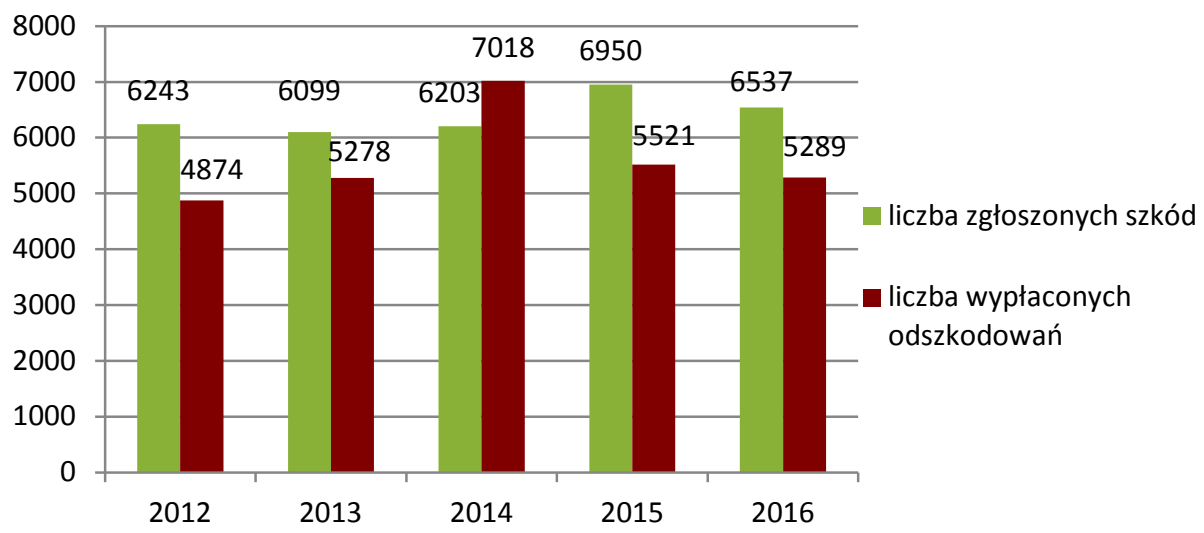

Wykres 3. Liczba zgłoszonych szkód w stosunku do liczby wypłaconych odszkodowań

Źródło: opracowanie własne na podstawie Raportu Rocznego UFG 2016 [8, dostęp: 20.03.2018].

\subsection{Obsługa rent}

Oprócz wypłat odszkodowań i świadczeń, UFG w ramach swojej działalności obsługuje renty. Na przestrzeni analizowanych lat liczba obsługiwanych rent sukcesywnie spadała. Pomiędzy 2012 rokiem a 2016 rokiem istnieje różnica 136 rent, co stanowi ogólny spadek o 13,7\%. Zmiany liczby obsługiwanych przez UFG w latach 2012-2016 rent prezentuje wykres 4.

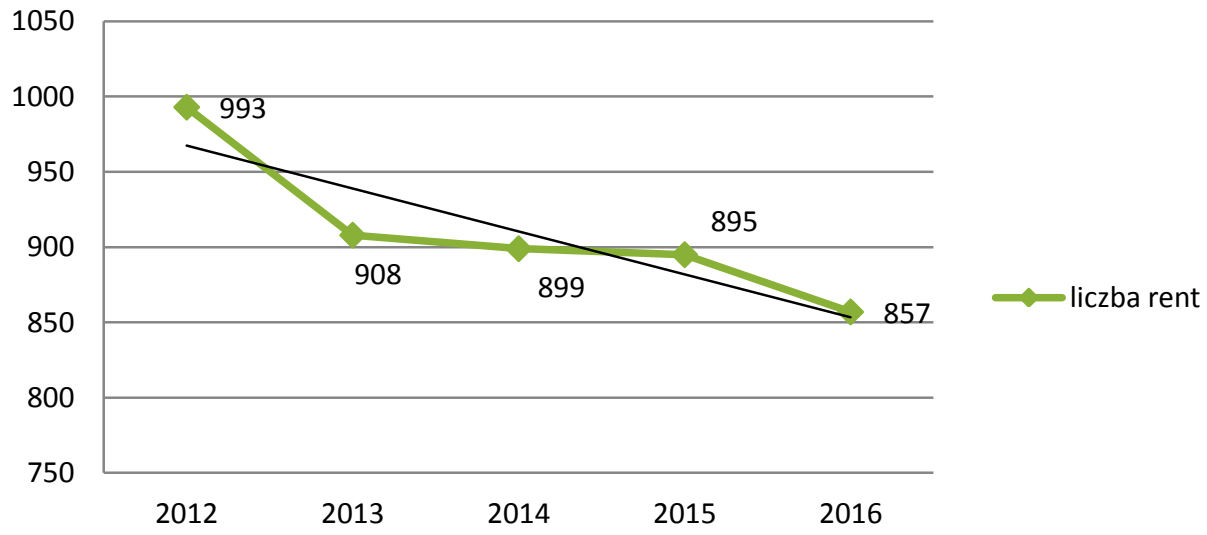

Wykres 4. Liczba rent w obsłudze UFG w latach 2012-2016

Źródło: opracowanie własne na podstawie Raportu Rocznego UFG 2016 [8, dostęp: 20.03.2018]. 


\section{5. Łączna kwota wyplaconych świadczeń}

Łączna kwota wypłaconych przez UFG świadczeń w latach 2012-2016 wyniosła $378,9 \mathrm{mln}$ zł. Średnio wartość wypłaconych odszkodowań wynosiła 74971 tys. zł. Wartość wypłaconych odszkodowań oraz dynamikę dla poszczególnych lat prezentuje tab. 1 .

Tabela 1. Wysokość wypłaconych odszkodowań przez UFG w latach 2012-2016

\begin{tabular}{|c|c|c|c|c|c|}
\hline Rok & 2012 & 2013 & 2014 & 2015 & 2016 \\
\hline $\begin{array}{c}\text { Kwota wypłaconych } \\
\text { odszkodowań (w tys. zł) }\end{array}$ & 60223 & 62151 & 68462 & 89485 & 94536 \\
\hline $\begin{array}{c}\text { Przyrosty względne } \\
\text { jednopodstawowe }\end{array}$ & - & 1,03 & 1,10 & 1,31 & 1,06 \\
\hline $\begin{array}{c}\text { Przyrosty względne } \\
\text { łańcuchowe. }\end{array}$ & - & 1,03 & 1,10 & 1,31 & 1,06 \\
\hline
\end{tabular}

Źródło: opracowanie własne na podstawie Raportu Rocznego UFG 2016 [8, dostęp: 20.03.2018].

\section{PODSUMOWANIE}

Należy stwierdzić, że działalność kompensacyjna UFG cieszy się coraz większą popularnością wśród społeczeństwa, gdyż poszkodowani wykazują coraz większą świadomość w zakresie pomocy jaką świadczy UFG. W analizowanym okresie wzrastała liczba zgłoszonych szkód. Spośród zgłoszonych szkód zdecydowana większość dotyczy zdarzeń OC komunikacyjnego, znacznie rzadziej są to szkody związane z OC rolników. Niski odsetek szkód wynikający z OC rolników nie jest konsekwencją braku zapotrzebowania na usługi UFG. Wynika to z faktu, że liczba użytkowników OC rolniczego jest mniej liczna. W związku z tym należy stwierdzić, że zapotrzebowanie na usługi UFG w obu grupach jest podobne.

Spośród wszystkich zgłoszonych szkód w analizowanym okresie, UFG zrealizował $87,4 \%$. Brak wypłaty świadczenia wynikał $z$ faktu istnienia ochrony ubezpieczeniowej i zwrotu akt do zakładów ubezpieczeń [Raport Roczny UFG 2013: 13, dostęp: 20.03.2018]. Główną przyczyną wypłaty świadczeń byli nieubezpieczeni sprawcy - średnio 75,9\% liczby wypłaconych świadczeń. Nieznacznie mniej popularnym powodem, dla którego wypłacano świadczenia (średnio 24,1\%) stanowił problem $\mathrm{z}$ ustaleniem tożsamości sprawcy wypadku. Zdarzenia związane z udziałem rolników stanowiły niespełna $1 \%$ wszystkich wypłacanych szkód. Linie trendu w opinii autorki mogą wskazywać, iż w przy- 
szłości należy się spodziewać spadku liczby nieidentyfikowalnych sprawców na korzyść wzrostu liczby sprawców nieubezpieczonych. Można również wysnuć wniosek, że malejąca liczba nieustalonych sprawców jest efektem skutecznej realizacji funkcji kontrolnej UFG, który pomaga w odnalezieniu sprawcy, przy współpracy z innymi organami do tego przeznaczonymi, np. policją czy strażą graniczną [Raport Roczny UFG 2015: 14, dostęp: 20.03.2018].

Na przestrzeni lat 2012-2016 w obsłudze UFG pozostawały renty. Ich ilość sukcesywnie spadała, skutkując finalnym obniżeniem o 13,7\% wartości początkowej. Linia trendu wskazuje, że w najbliższym czasie możemy spodziewać się ich dalszego spadku. Łączna kwota, jaką poniósł UFG na przestrzeni pięciu badanych lat, wynosi 378,9 mln zł. Wielkość tej kwoty pokazuje, jak duże jest zapotrzebowanie na organizację pełniącą funkcję kompensacyjną na polskim rynku ubezpieczeń.

Przedstawione w artykule dane dotyczące szkód i rent z tytułu upadłości lub likwidacji zakładów ubezpieczeń potwierdzają, iż Ubezpieczeniowy Fundusz Gwarancyjny w pełni realizuje funkcję kompensacyjną. Analiza i wniosek o corocznym przyroście kwoty wydatkowanej na pełnienie tej funkcji w opinii autorki świadczy, że kwota ta będzie wzrastać, a rynek zgłaszać coraz większe zapotrzebowanie w jej zakresie.

\section{BIBLIOGRAFIA}

Iwanicz-Drozdowska M., 2013, Ubezpieczenia, PWE, Warszawa.

Kwiecień I., 2011, Szkody osobowe kompensowane z ubezpieczenia komunikacyjnego OC, Poltext, Warszawa.

Monkiewicz J., Orlicki M., 2015, Ochrona konsumentów na rynku ubezpieczeniowym w Polsce, Poltext, Warszawa.

Monkiewicz M., 2007, Ubezpieczeniowe fundusze gwarancyjne na rynkach światowych, Dom Wydawniczy Elipsa, Warszawa.

Nowak A., Nowak S., Sopoćko A., 2009, Rynki finansowo-ubezpieczeniowe w warunkach kryzysu, Wydawnictwo Naukowe Wydziału Zarządzania Uniwersytetu Warszawskiego, Warszawa.

Pałczyńska-Mortka M., Żmigrodzki M., 2012, Instytucjonalne i prawne uwarunkowania polityki ubezpieczeniowej w III Rzeczypospolitej Polskiej, „Zeszyty Naukowe WSEI seria: ADMINISTRACJA", Wyższa Szkoła Ekonomii i Innowacji, Lublin.

Raporty roczne UFG 2016, https://www.ufg.pl/ucmservlet3?dDocName=UCM_UFG_175930.

Raporty roczne UFG 2015, https://www.ufg.pl/ucmservlet3?dDocName=UCM_UFG_049994.

Raporty roczne UFG 2014, https://www.ufg.pl/ucmservlet3?dDocName=UCM_UFG_009129.

Raporty roczne UFG 2013, https://www.ufg.pl/ucmservlet3?dDocName=UCM_UFG_009128.

Raporty roczne UFG 2012, https://www.ufg.pl/ucmservlet3?dDocName=UCM_UFG_009127.

Reda-Jakima Z., 2012, Sposób na tańszq polisę dla flot, „Rzeczpospolita. Ekonomia i Rynek”, B9, Warszawa.

Ronka-Chmielowiec W., 2016, Ubezpieczenia, C.H. Beck, Warszawa.

Sangowski T., 1998, Vademecum ubezpieczeń gospodarczych, Saga Printing, Poznań. 
Szaraniec M., 2013, Potrzeba zmian w zakresie funkcji kompensacyjnej UFG w razie niemożności wypłaty świadczenia pieniężnego w przypadku upadtości zakładu ubezpieczeń, „Acta Universitatis Lodziensis, Folia Iuridica", nr 72, Łódź.

Turkowska-Tyrluk E., 2005, Funkcje kontrolno-windykacyjne Ubezpieczeniowego Funduszu Gwarancyjnego w zakresie spetniania obowiazku ubezpieczenia, „Prawo Asekuracyjne”, nr 4 (45), Warszawa.

Ubezpieczeniowy Fundusz Gwarancyjny, Misja Funduszu, https://ufg.pl/infoportal/faces/pages_ home-page?_afrLoop=3610739083916644\&_afrWindowMode=0\&_adf.ctrl-state=ora2ntvjg_4 .

Ustawa z 22 maja 2003 r. o ubezpieczeniach obowiązkowych, Ubezpieczeniowym Funduszu Gwarancyjnym i Polskim Biurze Ubezpieczycieli Komunikacyjnych, art. 98 ust. 1 i 1a, http://prawo.sejm.gov.pl/isap.nsf/DocDetails.xsp?id=WDU20031241152.

\title{
COMPENSATING ACTIVITY OF THE INSURANCE GUARANTEE FUND IN POLAND IN 2012-2016
}

\begin{abstract}
The Insurance Guarantee Fund plays a unique role on the Polish insurance market. As the only institution in a comprehensive way protects insured and injured. The article discusses the UFG's missions and mode of operation. An analysis of the implementation of the compensatory function in the years 2012-2016 was presented and its interpretation was made. It has been demonstrated that the demand for services provided by UFG is growing.
\end{abstract}

Keywords: Insurance Guarantee Fund (UFG), Civil Liability (OC), insurance companies, compulsory insurance, compensating function. 